\title{
Endoparasitic fauna of two South American foxes in Chile: Lycalopex culpaeus and Lycalopex griseus
}

\author{
Fauna endoparasitária de duas raposas da América do Sul no Chile: \\ Lycalopex culpaeus e Lycalopex griseus

\begin{abstract}
Pablo Oyarzún-Ruiz¹,2 (1D; Sophia Di Cataldo3; Aitor Cevidanes³; Javier Millán4,5,6; Daniel González-Acuña1* (1) ${ }^{3}$ Programa de Doctorado en Medicina de la Conservación, Facultad de Ciencias de la Vida, Universidad Andrés Bello, Santiago, Chile

${ }^{4}$ Facultad de Ciencias de la Vida, Universidad Andrés Bello, Santiago, Chile

${ }^{5}$ Instituto Agroalimentario de Aragón-IA2, Universidad de Zaragoza - CITA, Zaragoza, España ${ }^{6}$ Fundación ARAID, Zaragoza, España
\end{abstract} \\ ${ }^{1}$ Laboratorio de Parásitos y Enfermedades en Fauna Silvestre, Facultad de Ciencias Veterinarias, Universidad de Concepción, Chillán, Chile \\ ${ }^{2}$ Becario ANID Programa de Doctorado en Ciencias Veterinarias, Facultad de Ciencias Veterinarias, Universidad de Concepción, Chillán, Chile
}

How to cite: Oyarzún-Ruiz P, Di Cataldo S, Cevidanes A, Millán J, González-Acuña D. Endoparasitic fauna of two South American foxes in Chile: Lycalopex culpaeus and Lycalopex griseus. Braz J Vet Parasitol 2020; 29(3): e006220. https://doi.org/10.1590/S198429612020055

\begin{abstract}
Native foxes face serious threats related to anthropic activities and the uncontrolled pets. However, the transmission of several pathogens such as parasites by domestic dogs is an important conservation issue with limited attention in Chile. The lack of a proper identification of the helminths of wild canids in the country, based mostly in coprological studies, limited our knowledge in potential interspecific transmission. Thus, the aim of the present survey was to identify the parasitic fauna of two native canids, the Andean fox (Lycalopex culpaeus) $(n=49)$ and Chilla (Lycalopex griseus) $(n=17)$, from several localities in Chile through a complete parasitological survey. Sixteen different species were identified, 9 of which are new host records for Andean fox and two for Chilla fox in South America, and three are recorded for first time in Chile. Also, five of them are of zoonotic concern and six are known to use domestic dogs as their principal hosts. These findings have implications for public health and the conservation of canids whose interspecific transmission of parasites with domestic dogs is confirmed through these findings. The need for an exhaustive surveillance of wild carnivores is emphasized considering these hosts as important sources of micro- and macroparasites.
\end{abstract}

Keywords: Culpeo fox, Chilla, endoparasites, Chile, conservation, public health.

\section{Resumo:}

As raposas nativas enfrentam sérias ameaças devido às atividades antrópicas e contato com animais de estimação sem controle. Entretanto, a transmissão de patógenos, tais como parasitas de cães domésticos, é uma questão importante na conservação das raposas que têm sido pouco abordadas no Chile. A falta de uma identificação adequada dos helmintos de canídeos silvestres no país, que se baseia principalmente, em estudos coprológicos, limita o conhecimento sobre uma potencial transmissão interespecífica de parasitas. Assim, o objetivo do presente estudo foi identificar a fauna parasitária em dois canídeos nativos: a raposa andina (Lycalopex culpaeus) $(n=49)$ e a raposa chilla (Lycalopex griseus) $(n=17)$, provenientes de várias localidades do Chile, por meio de um levantamento parasitológico completo. Foram identificadas 16 espécies de parasitas, nove correspondem a novos registros de hospedeiros para a raposa andina e dois para a raposa chilla na América do Sul. Três espécies de parasitas são registrados pela primeira vez no Chile, cinco são motivo de preocupação zoonótica e seis são conhecidos por usar cães domésticos como seus principais hospedeiros. Esses achados têm implicações em saúde pública e na conservação de canídeos, pois confirmam a transmissão interespecífica de parasitas desde cães domésticos. A necessidade de vigilância exaustiva dos carnívoros selvagens é enfatizada considerando-se esses hospedeiros como importantes fontes de micro e macroparasitas.

Palavras-chave: Raposa Culpeo, Raposa Chilla, endoparasitas, Chile, Conservação, Saúde pública. 


\section{Introduction}

Wild carnivores are considered as relevant sources of zoonotic pathogens, including viruses, bacteria, and parasites (Aguirre, 2009; Rubio et al., 2013). In Chile there are three species of wild canids, Andean fox or Culpeo fox (Lycalopex culpaeus), Chilla fox (Lycalopex griseus) and Darwin's fox (Lycalopex fulvipes), which also faces several threats related to hunting by farmers, fragmentation of habitat, competition and transmission of diseases by domestic canids (Jiménez \& Novaro, 2004). For South American wild canids, there is a fragmented knowledge regarding endoparasites (Moleón et al., 2015). In the particular case of Chile, most of the published parasitological records are related to ectoparasites such as fleas (Rubio et al., 2013; Poo-Muñoz et al., 2016), lice (Mey, 2003; GonzálezAcuña et al., 2007), mites (Verdugo et al., 2016; Briceño et al., 2020) and ticks (González-Acuña \& Guglielmone, 2005; Rubio et al., 2013). Furthermore, surveys for endoparasites through necropsies in wild foxes are rare (Wolffhügel, 1949; Alvarez, 1960, 1961; Medel \& Jaksic, 1988). Additional reports are based on coprological surveys (Jiménez et al., 2012; Rubio et al., 2013; Acosta-Jamett et al., 2018). Moreover, several of the helminth findings in Chilean foxes are identified only to the genus level with no further classification (see Fugassa, 2015). The scarce number of studies for endoparasites could be a consequence of the difficulties imposed by the acquisition of carcasses of these animals because of their protection by the State Law of Hunting, with the exception of Chilla fox from Tierra del Fuego Island, Chilean Patagonia, where is considered as a harmful species (Chile, 2017). In addition, Chile lacks a centralized wildlife diseases surveillance program, what further difficult the collection of carcasses.

Chile lacks of policies regard management of naturalized domestic dogs, which represent a threat to the health of wild canids (Daszak et al., 2000; Rubio et al., 2013). Thus, the aim of the present study was to report the occurrence and frequency of endoparasites and contribute with new findings to the parasitic fauna of native canids.

\section{Materials and Methods}

A total of 66 foxes (49 Andean foxes (Af) and 17 Chilla fox (Ch)) that died after their arrival to local rehabilitation centers or were road-killed formed part of the present survey. Additionally, helminths previously deposited in the parasitological collection from Laboratorio de Parásitos y Enfermedades en Fauna Silvestre at Universidad de Concepción, Chile, were included in this study. Foxes were analyzed between 1995-2019 from the following regions along Chile (number of the region and sample size per fox species are indicated between parenthesis); III Atacama region ( $C h, n=1$ ), IV Coquimbo region ( $A f, n=3 ; C h, n=1$ ), V Valparaíso region ( $A f, n=2 ; C h, n=3$ ), RM Metropolitan region ( $A f, n=18 ; C h, n=4$ ), VI Libertador General Bernardo O'Higgins region ( $A f, n=4 ; C h, n=2$ ), VII Maule region ( $A f, n=4 ; C h, n=3$ ), XVI Ñuble region (Af, $n=6$ ), VIII Biobío region (Af, $n=1$ ), XIV Los Ríos region ( $A f, n=1 ; C h, n=1$ ) and XI Aysén del General Carlos Ibáñez del Campo region ( $A f, n=1$ ), also 11 foxes whose locations were not recorded were included ( $A f, n=9 ; C h, n=2)$. Regarding the sites where foxes were sampled, 6 foxes came from rural areas (national parks and reserves), 47 from urbanized areas, 2 from rehabilitation centers and 1 from a zoo. With the exception of foxes from rehabilitation centers and zoos, and other three which were found dead in two national parks and one national reserve, all foxes were road-killed. The sampled sites included 10 of the 16 Political-Administrative regions present along Chile (Figure 1). Parasitological necropsy was performed according to Hofer et al. (2000), considering the analysis of digestive, respiratory and urogenital systems, also heart, liver, gallbladder, thoracic and abdominal cavities, and subcutaneous tissue. Helminths were recovered from animals, washed and relaxed in saline previous to be fixed in ethanol $80^{\circ}$ and proceed with the analysis. Furthermore, nematodes and pentastomids were diaphanized using Glycerine alcohol, meanwhile platyhelminthes were stained with Alum carmine, dehydrated in a series of alcohol concentrations from $70 \%$ to absolute alcohol, clarified with clove oil and mounted with Canada balsam (Lutz et al., 2017; Oyarzún-Ruiz \& González-Acuña, 2020). Helminth and pentastomid parasites were classified according to Erickson (1944), Petrochenko (1958), Yamaguti (1961), Quentin et al. (1968), Khalil et al. (1994), Riley (1986), Vicente et al. (1997), Santos et al. (2007), Anderson et al. (2009), Naem \& Asadi (2013) and Gomez-Puerta et al. (2017). Parasitological descriptors such prevalence $(P)$, mean intensity $\left({ }_{M} I\right)$, mean abundance $\left({ }_{M} A\right)$ and range $(R)$ were calculated and interpreted according to Bush et al. (1997). Confidence intervals with 95\% of confidence were expressed between parenthesis for every prevalence.

Because the limited sample size for both canids from diverse climatic regions, it was not possible to estimate statistical comparisons. 


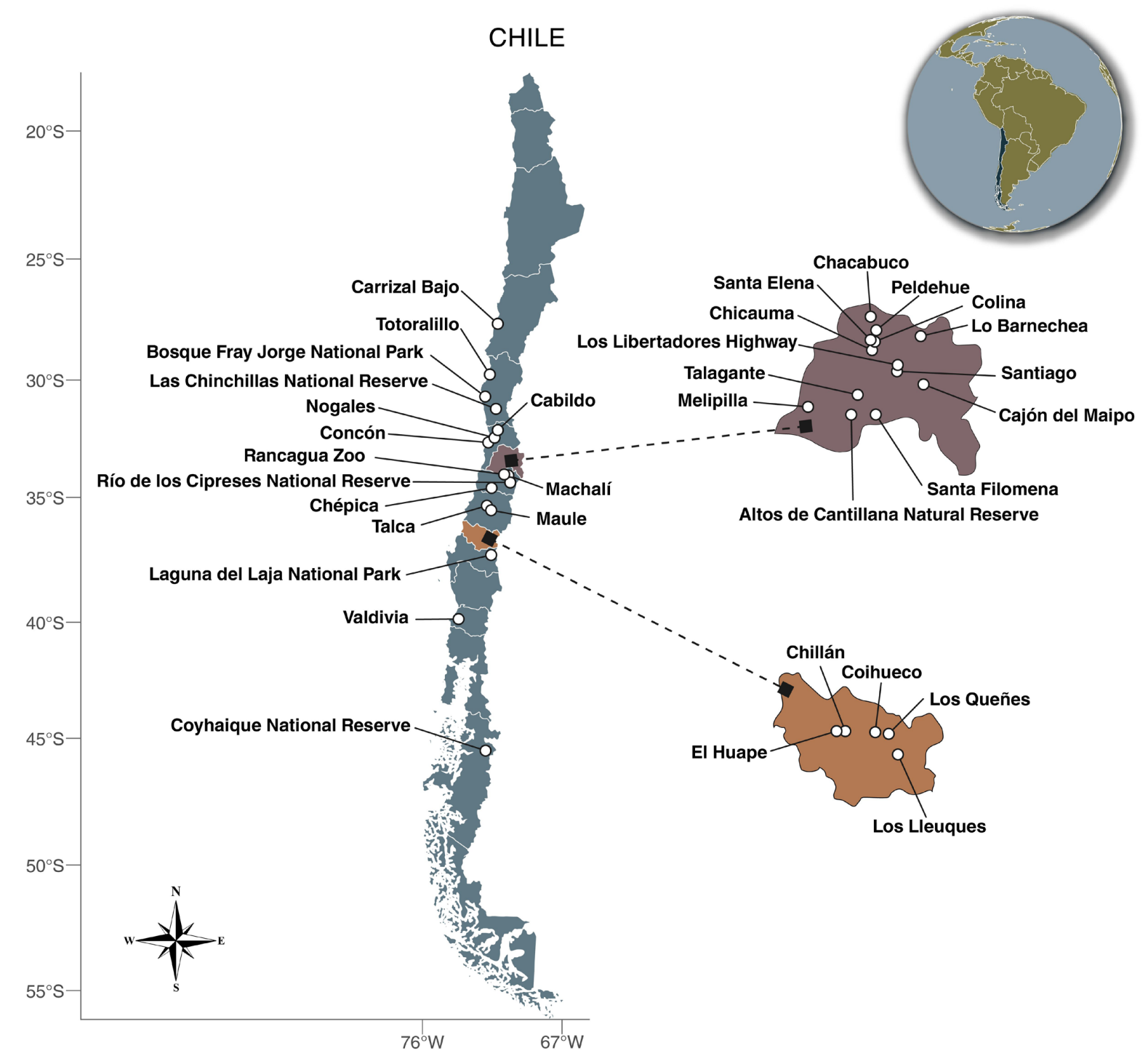

Figure 1. Map detailing the locations along Chile where native foxes were sampled.

\section{Results}

Overall, $86.36 \%(77.99-94.73 \% ; 57 / 66)$ of foxes were positive for at least one endoparasite species, including $91.84 \%$ (84.17-99.50\%; 45/49) of the Andean foxes and $70.59 \%$ (48.93-92.25\%; 12/17) of the Chilla foxes. A total of 16 different taxa of endoparasites belonging to 4 different phyla, were observed (Table 1). The species were the following: Nematoda; Acanthocheilonema sp. (Af, $\mathrm{P}=2.04 \%$ ), Contracaecum sp. (Af, $\mathrm{P}=2.04 \%)$, Oslerus (Oslerus) osleri (Af, $\mathrm{P}=12.24 \%$; Ch, $\mathrm{P}=5.88 \%)$, Physaloptera rara (Af, $\mathrm{P}=4.08 \% ; \mathrm{Ch}, \mathrm{P}=5.88 \%)$, Protospirura numidica $(\mathrm{Af}, \mathrm{P}=2.04 \%)$, Pterygodermatites sp. (Af, $P=2.04 \%)$, Spirocerca sp. (Af, $P=10.2 \%)$, Toxascaris leonina ( $A f, P=36.73 \% ; C h, P=11.76 \%$ ), Toxocara canis (Af, $\mathrm{P}=12.24 \%)$, Uncinaria stenocephala (Af, $\mathrm{P}=2.04 \%)$, Cestoda; Mesocestoides sp. (Af, $\mathrm{P}=12.24 \%$; $\mathrm{Ch}, \mathrm{P}=23.53 \%)$, Spirometra sp. (sparganum) (Af, $\mathrm{P}=2.04 \%)$, Taenia hydatigena (Af, $\mathrm{P}=40.82 \%$; $\mathrm{Ch}, \mathrm{P}=5.88 \%$ ), Trematoda; Ascocotyle (Ascocotyle) felippei (Af, $\mathrm{P}=4.08 \%$ ), Acanthocephala; Centrorhynchus spinosus (Af, $\mathrm{P}=2.04 \%)$, and Pentastomida; Linguatula serrata (Af, $\mathrm{P}=2.04 \%$ ) (Figure 2 and Figure 3). See Table 1 for details regard hosts, parasitological descriptors, organs parasitized and localities. All 16 species were found in L. culpaeus, meanwhile only 5 of them were recorded for L. griseus.

Parasites were retrieved from the digestive tract $(96.49 \%, 55 / 57)$, respiratory $(14.04 \%, 8 / 57)$ and urinary systems $(1.75 \%, 1 / 57)$ of foxes, and the abdominal cavity was also parasitized in one case $(1.75 \%, 1 / 57)$. Parasitism with one species of parasite was recorded in $54.39 \%$ of foxes (31/57), meanwhile infections with two and three parasite species were recorded for $24.56 \%$ (14/57) and $12.28 \%$ (7/57) of foxes, respectively. Exceptionally, there 


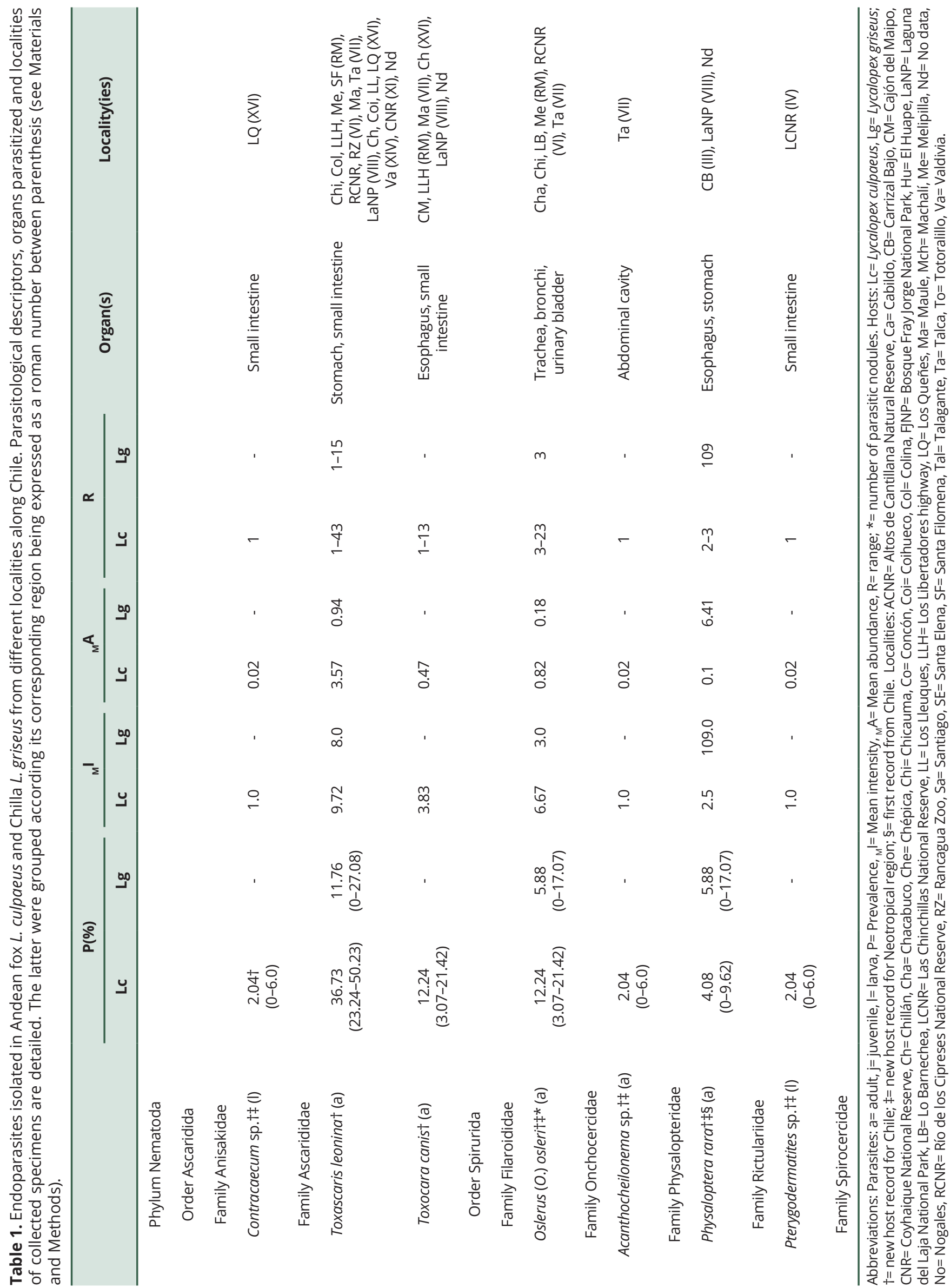




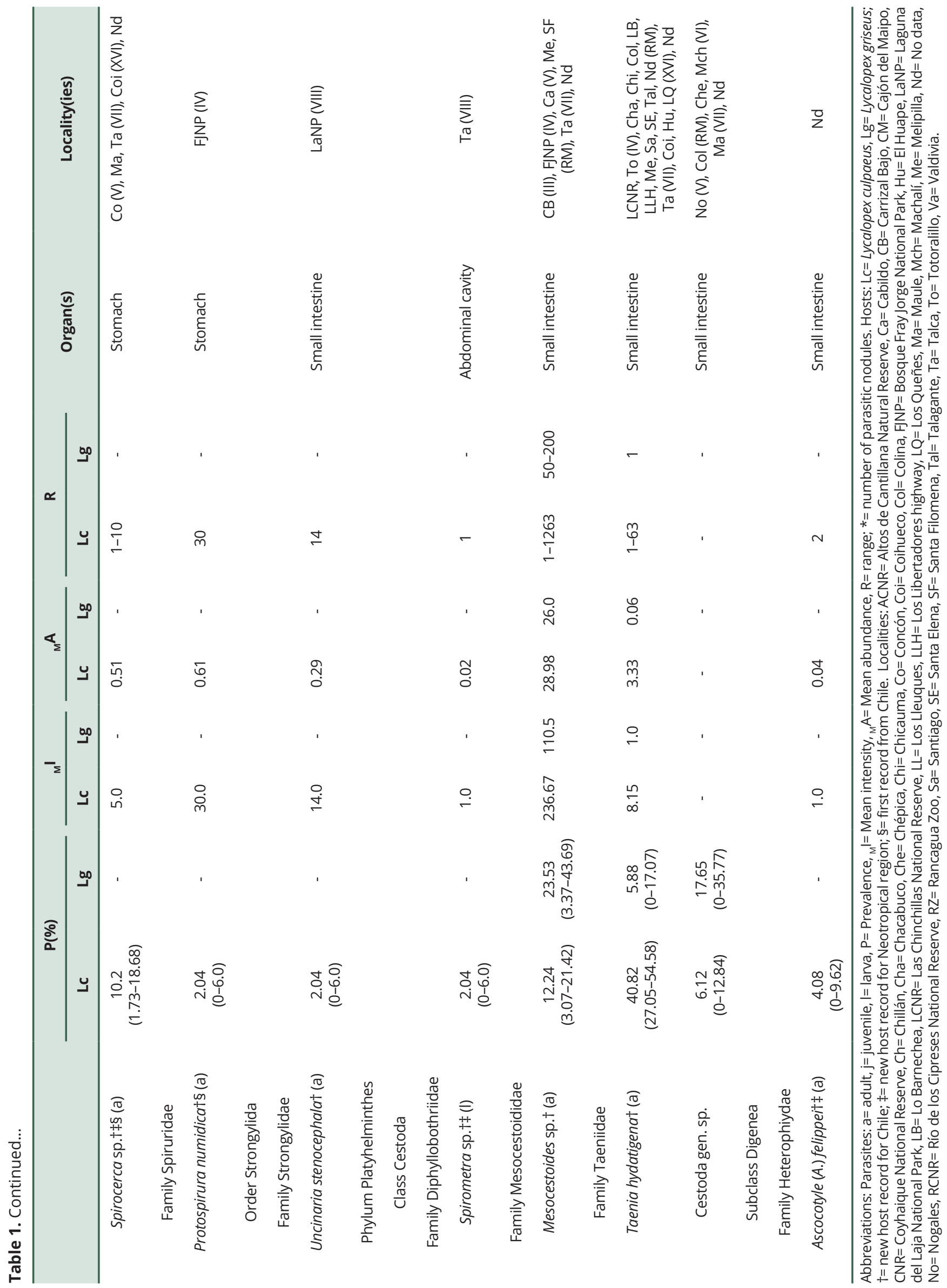




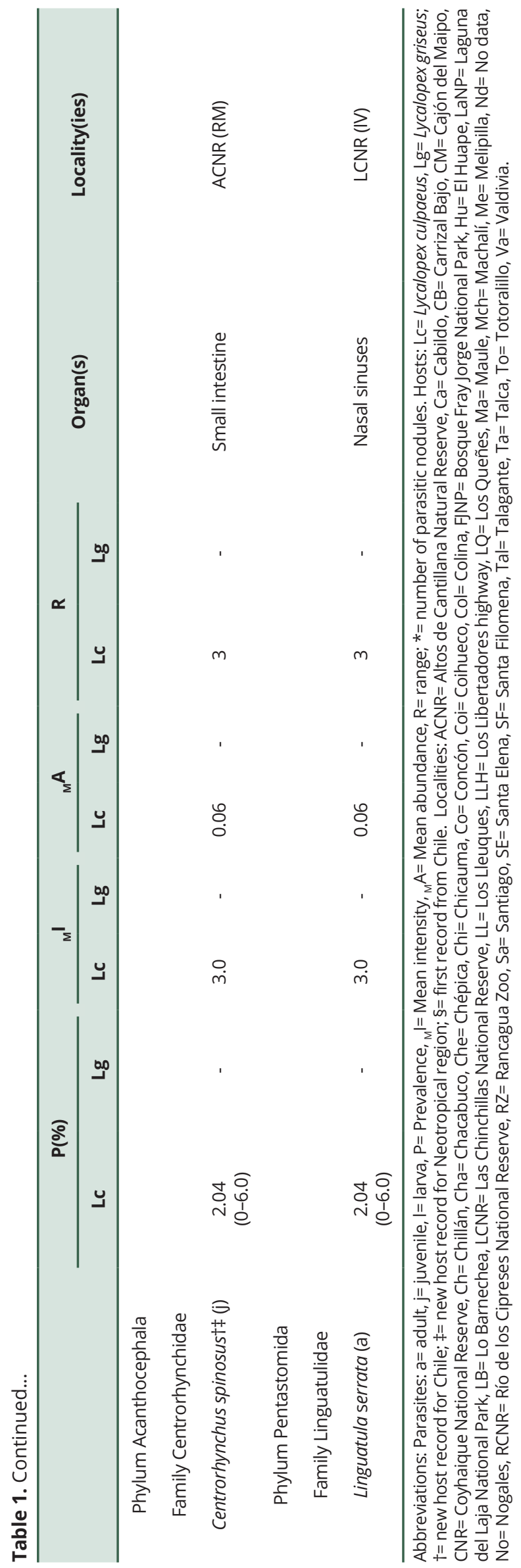



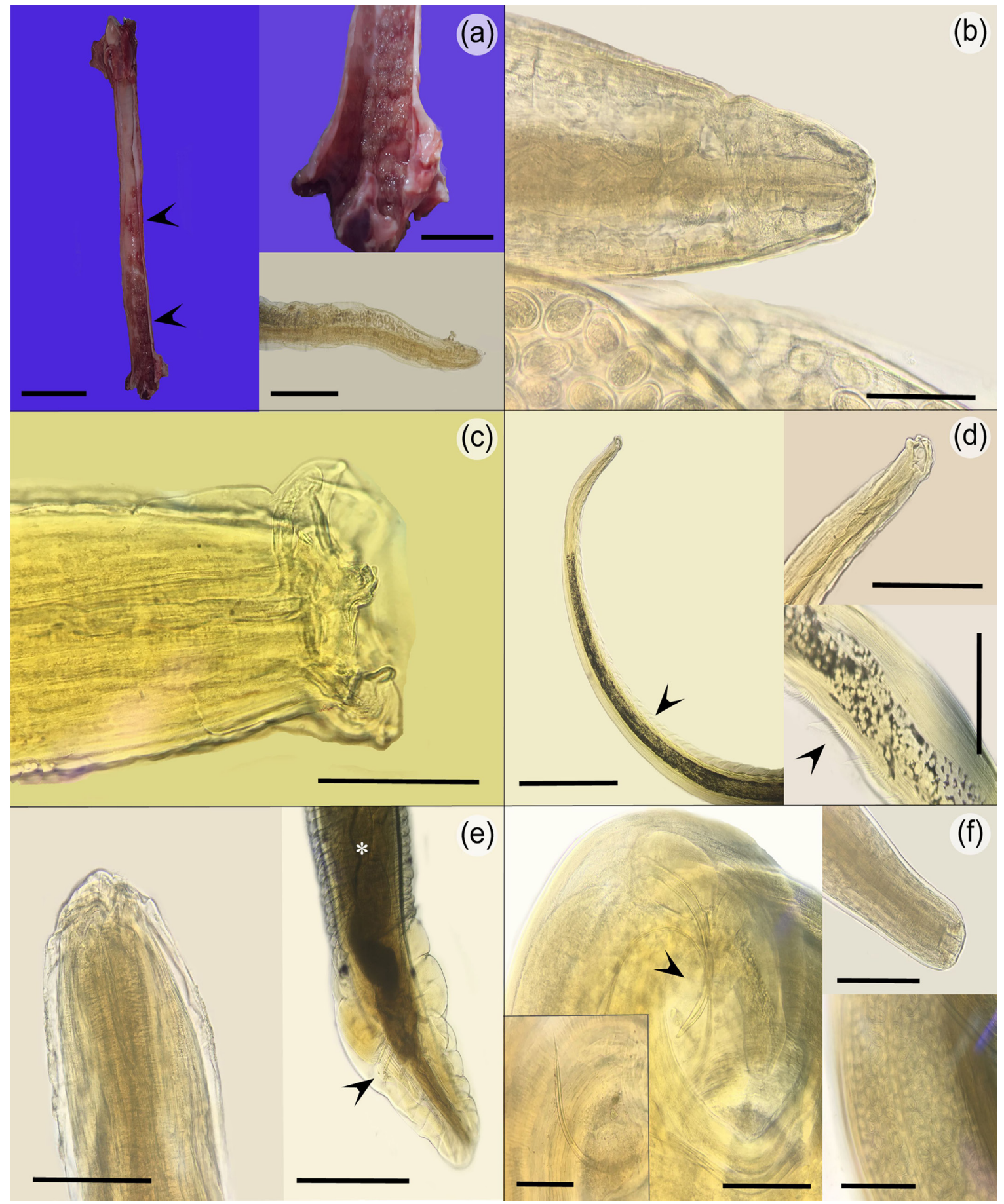

Figure 2. (a) Trachea of a Culpeo fox with several parasitic nodules near the medial, caudal and carina parts of trachea (left, upper right side) (arrowheads). Note the uterus of an ovigerous female of Oslerus (Oslerus) osleri filled with several embryonated eggs (bottom right side). Scale bars= $6 \mathrm{~cm}$ (left), $3 \mathrm{~cm}$ (upper right side), $500 \mu \mathrm{m}$ (bottom right side); (b) Anterior end of an ovigerous female of Acanthocheilonema sp. isolated in the abdominal cavity of a Culpeo fox, note the flattened lips, narrow esophagus and also the presence of multiple embryonated eggs. Scale bar $=250 \mu \mathrm{m}$; (c) Anterior end of Physaloptera rara isolated in the stomach of a Chilla fox, note its characteristic cephalic collarette and prominent triangular lips. Scale bar= $500 \mu$ m; (d) Pterygodermatites sp. isolated in the small intestine of a Culpeo fox; Anterior third of body of an immature worm, note the rows of comb-like spines along the body (arrowhead) (left). Detail of anterior end with a dorsal oral aperture armed with denticles (upper right side). Close up of comb-like spines over the body of the worm (arrowhead) (bottom right side). Scale bars= $1 \mathrm{~mm}$ (left), $500 \mu \mathrm{m}$ (right); (e) Spirocerca sp. isolated from the stomach of a Culpeo fox. Anterior end of the worm characterized by non-evident lips (left). Posterior end of male worm with unequal spicules (white asterisk) also, caudal alae present. Note pedunculated papillae (arrowhead) (right). Scale bars $=500 \mu \mathrm{m}$; (f) Protospirura numidica isolated from the stomach of a Culpeo fox. Spiral posterior end of male worm with its unequal spicules (left), one is thin and pointed (image inserted), meanwhile the other is thick and stout (arrow head). Anterior end with its prominent lateral lips (upper right side). Ovigerous female worms with embryonated eggs in the uterus (bottom right side). Scale bars $=500 \mu \mathrm{m}$. 


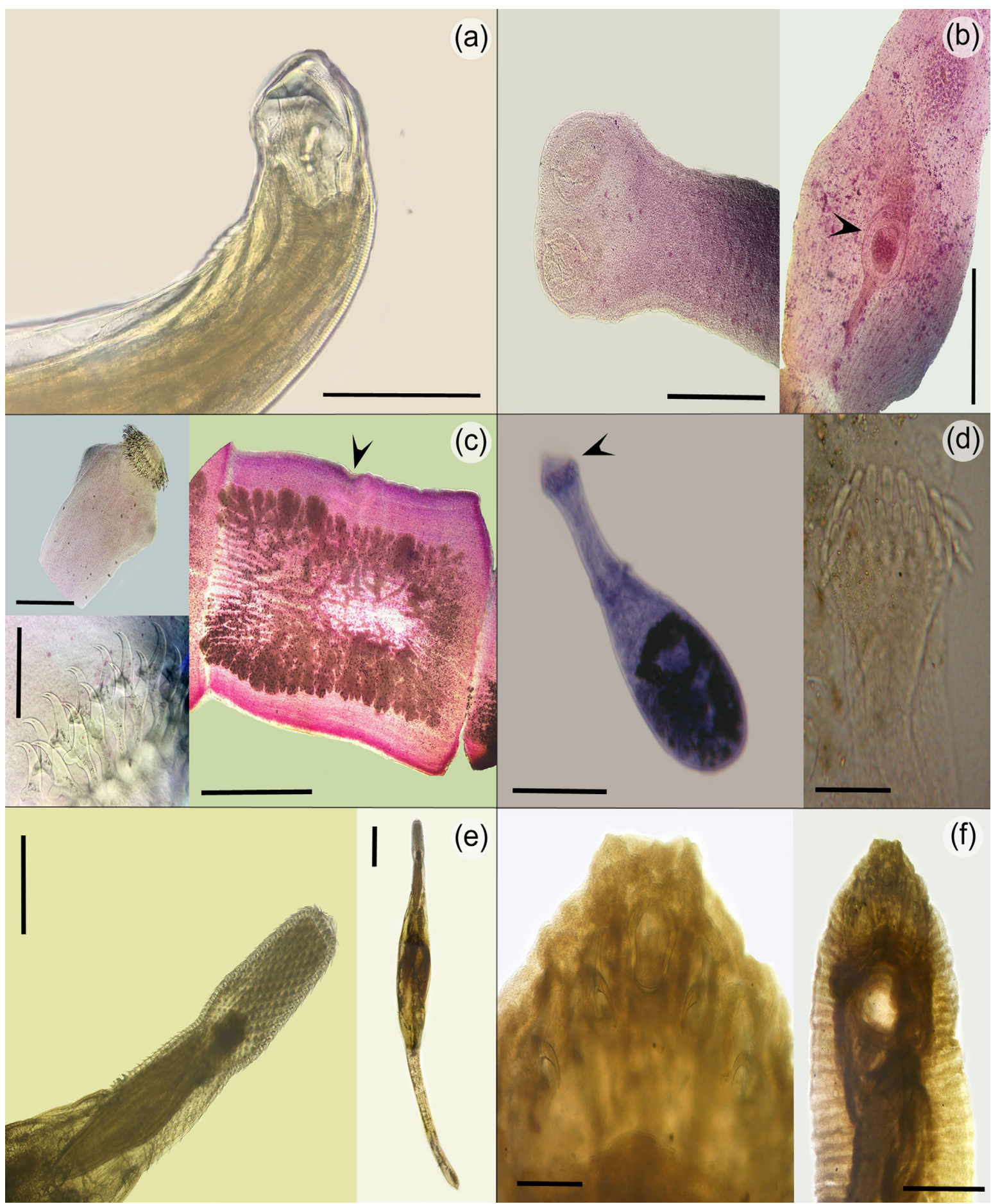

Figure 3. (a) Anterior end of Uncinaria stenocephala bent dorsally, oral aperture armed with a pair of semilunar cutting plates. This worm was isolated from the small intestine of a Culpeo fox. Scale bar= $1 \mathrm{~mm}$; (b) Mesocestoides sp. isolated from the small intestine of a Chilla fox. Scolex unarmed with its muscular four suckers (left). Mature proglottid with its typical paruterine organ (arrowhead) (right). Scale bars $=500 \mu \mathrm{m}$ (left), $1 \mathrm{~mm}$ (right); (c) Taenia hydatigena isolated from the small intestine of a Culpeo fox. Scolex armed with a double row of hooks and four muscular suckers (left). Ovigerous proglottid with its branched uterus filled with eggs. Note the presence of genital pore in the lateral border of the proglottid (asterisk) (right). Scale bars $=1 \mathrm{~mm}$ (upper left side), $500 \mu \mathrm{m}$ (bottom left side, right); (d) Ascocotyle felippei collected from the small intestine of a Culpeo fox. Worm in toto with an elongated forebody and dilated hindbody, note the uterus filled with eggs (left). Note the two circles of cephalic spines around oral sucker (arrowhead) (right). Scale bars $=50 \mu \mathrm{m}$ (left), $12.5 \mu \mathrm{m}$ (right); (e) Centrorhynchus spinosus isolated from the small intestine of a Culpeo fox. Cylindrical proboscis armed with 32 longitudinal rows of 24 hooks each and neck covered with spines. Note the cylindrical shape of proboscis (left). Immature worm in toto, note the nearly cylindrical body (right). Scale bars $=500 \mu \mathrm{m}$ (left), $1 \mathrm{~mm}$ (right); (f) Linguatula serrata collected from the nasal sinuses of a Culpeo fox. Anterior third of body armed with four hooks around the sclerotized oral aperture (left). Middle part of the body, suggesting a tongue-shaped body with its typical transversal striations (right). Scale bars $=500 \mu \mathrm{m}$ (left), $2 \mathrm{~mm}$ (right). 
were infections with four and six species of helminths in one fox each (1.75\%, 1/57). There were co-infections between digestive and respiratory parasites $(12.28 \%, 7 / 57)$ and among the three systems $(16.67 \%, 1 / 57)$. Regard co-infections, when Mesocestoides sp. showed a high parasitic load, there was a minimal load or absence of T. hydatigena (e.g. 100 vs 2 worms or 1263 vs 0 worms). On the other hand, there was a high parasitic load for T. hydatigena when Mesocestoides sp. showed a minimal load (e.g. 63 vs 1 worms). Additionally, in $29.82 \%$ of foxes there was co-infection between different phyla (17/57). The highest parasitic burden was 1263 parasites, meanwhile the lowest was one parasite.

\section{Discussion}

The present study is so far the most complete survey for endoparasites in wild foxes in Chile, and provides with new data about the presence and distribution of these parasites, with nine new host records for Andean fox and two for Chilla fox in South America, and three new records for the country. Overall, the high prevalence of parasitic infection was similar to previous studies in wild canids from Europe (Shimalov \& Shimalov, 2002, 2003; Bružinskaitè-Schmidhalter et al., 2011; Al-Sabi et al., 2013) and South America (Ruas et al., 2008; Moleón et al., 2015).

Both $T$. canis and $T$. leonina are very common ascarid worms among wild canids worldwide (Erickson, 1944; Seesee et al., 1983; Shimalov \& Shimalov, 2002, 2003; Bružinskaitė-Schmidhalter et al., 2011; Okulewicz et al., 2012; Al-Sabi et al., 2013; Figueiredo et al., 2016), including Neotropics (Deem \& Emmons, 2005; Zanini et al., 2006; Vieira et al., 2008; Fugassa, 2015; Moleón et al., 2015). Both canid species studied here have been found parasitized by them in Argentina (Stein et al., 1994; Zanini et al., 2006). Toxocara canis use domestic dogs as its principal host, thus its isolation could represent a consequence of the interaction between domestic and wild canids in rural areas (Stein et al., 1994; Okulewicz et al., 2012; Moleón et al., 2015). In Chile both T. canis and T. leonina were reported previously only on Darwin's fox by Jiménez et al. (2012) and Acosta-Jamett et al. (2018) through coprological analysis. In the present study, T. canis was isolated only from Andean fox, meanwhile T. leonina from both foxes. The frequent approach of Andean foxes to human settlements searching for food (Jiménez \& Novaro, 2004) would facilitate the contact with rural dogs, thus explaining their parasitism by $T$. canis. Notwithstanding the above, $T$. leonina was the most prevalent ascarid worm (36\% vs 12\%), which agrees with Okulewicz et al. (2012), who suggest a dominance of $T$. leonina over $T$. canis in wild canids.

Oslerus (Oslerus) osleri is a cosmopolitan nematode inhabiting tracheobronchial nodules in domestic and wild canids around the globe (Seesee et al., 1983; Avelar et al., 2013; Bowman, 2014). In the present study, all nodules were found in trachea, mostly near tracheal carina, and a few in the bronchi. Additionally, two male worms were found in the urinary bladder, probably as a consequence of an erratic migration. In Chile, this species was previously recorded in domestic dogs from Santiago (Luengo \& Arata, 1970; Muñoz et al., 2007). Embryonated eggs were also found in feces of the Darwin's fox (Jiménez et al., 2012) and an unidentified native fox by Luengo \& Arata (1970). Furthermore, there are additional records from other Neotropical canids, such as Hoary fox (Lycalopex vetulus) and Maned wolf (Chrysocyon brachyurus) (Avelar et al., 2013). Notwithstanding the above, Dunsmore \& Spratt (1979) suggested foxes as accidental hosts, with dogs as principal hosts for this parasite.

Acanthocheilonema is a filariid worm which parasites mammals worldwide, with Acanthocheilonema reconditum being the most studied species in canids, which is transmitted by the ingestion of sucking lice and fleas (Bowman, 2014). In the case of Chile, this species has been isolated only on domestic dogs (Alcaíno \& Gorman, 1999) with a similar situation occurring in Brazil (Vicente et al., 1997). In the present study, one female with embryonated eggs was isolated in the abdominal cavity of one Andean fox. Due to the lack of male worms, the taxonomical classification to species level could not be achieved (Anderson et al., 2009).

Physaloptera rara parasitizes domestic and wild canids and felids from Asia, Europe, North America and Mexico (Erickson, 1944; Morgan, 1944; Yamaguti, 1961; Seesee et al., 1983; Naem \& Asadi, 2013), using crickets, cockroaches and beetles as intermediate hosts (Yamaguti, 1961). In South American canids, Physaloptera digitata, Physaloptera praeputialis, Physaloptera terdentata, Physaloptera sp. and an unidentified physalopterid has been recorded for Crab-eating fox (Cerdocyon thous), Pampas fox (Lycalopex gymnocercus) and Maned wolf from Argentina (Fugassa, 2015), Bolivia (Deem \& Emmons, 2005) and Brazil (Vieira et al., 2008; Lima et al., 2013). Also, P. clausa was reported for Andean and Chilla foxes in Argentina by Stein et al. (1994). Caballero \& Peregrina (1938) recorded this species in Grey fox (Urocyon cinereoargenteus) from Mexico, although according to Morgan (1944) and Yamaguti (1961) this species really corresponds to P. rara. Rubio et al. (2013) recorded eggs of Physaloptera sp. on an Andean fox, which could belong to the species here reported. 
The nematode Pterygodermatites parasitizes wild mammals with subgenus $P$. (Multipectines) parasitizing wild carnivores worldwide and P. (Paucipectines) being found in Neotropical rodents (Anderson et al., 2009). The former subgenus has been recorded in Neotropical canids such Crab-eating fox (Lima et al., 2013; Pinheiro et al., 2018) and other species from North America (Seesee et al., 1983). Considering that the retrieved worm corresponded to an immature female, it is difficult to attribute it to a subgenus. Also, in Chile, this genus has been recorded in native rodents (Cattan et al., 1992; Landaeta-Aqueveque et al., 2018), thus, it cannot be discarded as originating from these prey (e.g. Bružinskaitè-Schmidhalter et al., 2011; Acosta-Jamett et al., 2018).

Protospirura numidica is considered a parasitic nematode of mammals, mostly rodents (Quentin et al., 1968; Vicente et al., 1997). However, there are some records in wild canids such Chilla and Andean fox from Argentina (Stein et al., 1994), and coyotes (Canis latrans) from USA (Erickson, 1944; Seesee et al., 1983). Furthermore, this genus has been reported in native rodents such long-haired akodont (Abrothrix longipilis) and olive grass mouse (Abrothrix olivaceus) (Cattan et al., 1992; Landaeta-Aqueveque et al., 2018). Although canids have been suggested as accidental hosts (Stein et al., 1994), ovigerous females and adult males were found in the stomach of one Andean fox in the present study, which would suggest this fox as a suitable host for this species. This situation has been previously suggested by Erickson (1944), who stated this nematode as a common finding in coyotes. Nevertheless, additional studies are required to validate this hypothesis.

Genus Spirocerca parasitize the esophagus and stomach of canids, originating nodules in the mucosa of these organs. Spirocerca lupi is a worldwide distributed species, parasitizing wild and domestic canids (Erickson, 1944; Yamaguti, 1961). This nematode has an indirect lifecycle with dung beetles as intermediate hosts, and reptiles and rodents as paratenic hosts (Anderson, 2000). In South America, S. Iupi and Spirocerca sp. have been recorded in Crab-eating fox and domestic dogs from Brazil (Vicente et al., 1997; Pinheiro et al., 2018) and Andean fox from Peru (Gomez-Puerta et al., 2018). However, in Europe, red foxes (Vulpes vulpes) are host for a different species, Spirocerca vulpis (Rojas et al., 2018). In the present study these nematodes were embedded in the gastric mucosa of Andean foxes, which differs from the findings in Peru (Gomez-Puerta et al., 2018), where the parasites were found in the esophagus and aorta. Additional molecular analysis should be done in the future to establish the specific identification of these worms.

Uncinaria stenocephala is a common parasite from domestic dogs (Alcaíno \& Gorman, 1999; Bowman, 2014) and other wild canids (Shimalov \& Shimalov, 2002, 2003; Bružinskaitè-Schmidhalter et al., 2011; Al-Sabi et al., 2013). In South America, this genus has been recorded for Crab-eating fox and Maned wolf from Bolivia (Deem \& Emmons, 2005) and Brazil (Vicente et al., 1997; Vieira et al., 2008). There are previous records of this nematode in Andean foxes from Argentina (Moleón et al., 2015) and Peru (Moro et al., 1998), and also an unidentified species in Chilla foxes from Argentina (Zanini et al., 2006).

The cestode Mesocestoides parasitizes wild carnivores as definitive hosts, and reptiles and small mammals as intermediate hosts (Al-Sabi et al., 2013; Bowman, 2014). This genus has a complex taxonomy imposed by its morphological variation and presence of cryptic species, requiring a molecular approach to establish its specific identification (Padgett et al., 2005). There are few records from South American canids with Crab-eating fox and Maned wolf as hosts from Argentina (González et al., 2013) and Brazil (Vieira et al., 2008). Furthermore, Mesocestoides lineatus has been recorded in Andean fox from Argentina (Moleón et al., 2015) and Peru (Moro et al., 1998), and Mesocestoides sp. in Chilla fox from Argentina (Zanini et al., 2006). Meanwhile in Chile, there is a record only in domestic dogs (Alcaíno \& Gorman, 1999).

Carnivores act as definitive hosts for Spirometra spp. with amphibians and reptiles as intermediate hosts for this parasite (Ruas et al., 2008; Bowman, 2014; Almeida et al., 2016). Previous surveys have recorded eggs of this genus in feces of Andean and Darwin's fox from Chile (Rubio et al., 2013; Acosta-Jamett et al., 2018). However, occasionally carnivores could act as accidental hosts after the ingestion of infective eggs, as reported for other wild canids (Rego \& Schäffer, 1992; Shimalov \& Shimalov, 2002). Wolffhügel (1949) isolated spargana of Spirometra cf. erinaceieuropaei from Chilla fox and domestic dogs, and also in rodents and salmonids from Southern Chile. Thus, the present isolation of a sparganum in a Culpeo would be considered as an accidental finding. Due to the complexity on taxonomy about these tapeworms, a molecular analysis is required to achieve the lowest taxonomical classification (Almeida et al., 2016).

Taenia hydatigena is a cosmopolitan tapeworm, parasitizing domestic and wild canids as definitive hosts (Erickson, 1944; Shimalov \& Shimalov, 2002, 2003; Bowman, 2014) and ruminants as intermediate hosts (Bowman, 2014). In South America, it was found in Pampas fox (Moleón et al., 2015). In Chile, the larvae Cysticercus tenuicollis has been recorded from native deers (Hippocamelus bisulcus and Pudu puda) (Povilitis, 1998; González-Acuña, 2002), 
meanwhile adult stages have been recorded only from domestic dogs (Alcaíno \& Gorman, 1999). On the other hand, there is a previous record in Andean and Chilla foxes from Argentina (Zanini et al., 2006) and Peru (Moro et al., 1998). Medel \& Jaksic (1988) isolated an unidentified Taenia in an Andean fox, also, Jiménez et al. (2012) and Acosta-Jamett et al. (2018) reported unidentified taeniid eggs from Darwin's fox in Southern Chile. These findings could belong to the species here reported.

Ascocotyle (Ascocotyle) felippei was the only fluke isolated. This species uses aquatic snails and fishes as first and second intermediate hosts, respectively. It has been widely recorded parasitizing fish-eating birds from South America (Santos et al., 2007). Meanwhile in Chile, A. (A.) felippei has been found in the common kestrel from Central Chile (González-Acuña et al., 2011). On the other hand, Ascocotyle (Phagicola) longa is another species which has been isolated in North American canids, such wolves (Canis lupus), red foxes and coyotes (Erickson, 1944). In Chile, it has been recorded in domestic dogs (Alcaíno \& Gorman, 1999). Additionally, Acosta-Jamett et al. (2018) recorded unidentified eggs of flukes for Darwin's fox, although these were attributed to rodent prey.

The acanthocephalan Centrorhynchus parasitizes birds as its main definitive hosts with cockroaches as intermediate, and reptiles, amphibians and rodents as paratenic hosts (Petrochenko, 1958). In Chile, C. spinosus has been recorded on Magellanic-horned owl (Bubo magellanicus) (Grandón-Ojeda et al., 2018). Meanwhile for native carnivores, there is only one record of unidentified acanthocephalans for Chilla fox (liménez \& Novaro, 2004). However, other predatory mammals such Crab-eating fox, Maned wolf from Argentina and Brazil have been found with Centrorhynchus sp. (Ruas et al., 2008; González et al., 2013). These authors considered the parasitism by immature forms of this genus as accidental findings in these mammals.

Linguatula serrata is a heteroxenous pentastomid distributed worldwide, with canids as definitive hosts and several mammal species as intermediate hosts (Christoffersen \& de Assis, 2013; Bowman, 2014). It has been recorded previously on Andean fox in the Metropolitan region, Chile, by Alvarez (1960). Nymphs have been found parasitizing native rodents (Abrocoma bennetti, Octodon degus) and deers (P. puda), and lagomorphs (Lepus europaeus, Oryctolagus cuniculus) (Alvarez, 1960; Courtin et al., 1979; Fugassa, 2015), domestic ruminants and dogs (Alcaíno \& Gorman, 1999). Furthermore, maned wolves and domestic dogs from Costa Rica and Paraguay are included as additional definitive hosts (Christoffersen \& de Assis, 2013).

As is well-known, several of the recorded endoparasites have indirect life cycles, with the prey of these foxes, e.g. insects, reptiles, lagomorphs and rodents, among others, acting as intermediate hosts (see Álvarez, 1960; Courtin et al., 1979; Jiménez \& Novaro, 2004; Fugassa, 2015). Even so, some parasitological findings seem to incorporate some unknown dietary items for Andean foxes such as fishes, which are used by $A$. (A.) felippei and Contracaeum sp. as intermediate and paratenic hosts, respectively (Anderson, 2000; Santos et al., 2007). Although both fish-borne parasites were isolated only from Andean fox, there is a previous report of fish as a dietary item for Chilla fox (Martínez et al., 1993), which could explain this finding, considering both foxes share several dietary items (Jiménez \& Novaro, 2004).

A potential negative interaction between both isolated tapeworms was suspected; Mesocestoides sp. vs T. hydatigena. This phenomenon could represent an antagonistic interaction between these parasites (Poulin, 2007), considering both use the small intestine as its habitat (Khalil et al., 1994). However, additional data are required to test this observation.

Although most studies from South American canids are focused on digestive parasites (see Fugassa, 2015), surveys should consider looking for extra-intestinal parasites as well (Deem \& Emmons, 2005), which are important for the helminthological and public health overview (Avelar et al., 2013; Christoffersen \& de Assis, 2013; Bowman, 2014), as it has been confirmed in the present study.

Regarding the new records of parasites for each fox distributed in Chile; 15 and 5 species are new for Andean and Chilla fox, respectively. Furthermore, considering the records from its native distribution in the Neotropical region, 9 are new host records for Andean fox and 2 for Chilla fox (see Table 1). Moreover, P. numidica, P. rara, Spirocerca sp. are reported for first time in Chile. The noticeable number of new records for these two canids highlight the need to surveying continuously wild carnivores and make complete parasitological necropsies when access to carcasses is possible.

Among the isolated parasites, there are some which have importance for biological conservation by having dogs as their principal hosts, e.g. Acanthocheilonema sp., L. serrata, O. (O.) osleri, T. canis, T. hydatigena and U. stenocephala (Dunsmore \& Spratt, 1979; Okulewicz et al., 2012; Bowman, 2014). Considering the modifications of landscapes due to anthropic activities, there is an increasing risk of transmission of pathogens between domestic and wild carnivores, even to humans (Daszak et al., 2000). Thus, the isolation of these helminths in wild canids seems to be 
a consequence of the transmission through the domestic-wild interface (Rubio et al., 2013; Acosta-Jamett et al., 2018). In addition to this, parasites with zoonotic potential were isolated in the present survey, e.g. L. serrata, Mesocestoides sp., Spirometra sp., T. canis and T. leonina (Rego \& Schäffer, 1992; Okulewicz et al., 2012; Bowman, 2014). Hereafter, these and other endoparasites such Dioctophyme renale, Dirofilaria spp., Echinococcus granulosus, Eucoleus aerophilus, Pearsonema plica and Trichuris vulpis (Deem \& Emmons, 2005; Bowman, 2014), require attention to determine their range of wild hosts, pathological consequences, ecology and the impact they would have over human health.

As was stated in the present study, several parasitic species are reported for first time in these two foxes, with some of them using domestic dogs as its main hosts. Also, important zoonotic parasites were reported. All these findings highlight the need for more studies related to the pathogens transmitted through the interaction between domestic and wild vertebrates, and the potential consequences they could have over wildlife and human health.

\section{Acknowledgements}

We thankful to Drs. Fabiana Drago and Nathalia Scioscia for supporting us with publications, also to Félix Varas, Lucas Aravena, Valentina Aravena, Natalia Pino and Paula Mujica for laboratory assistance. Sebastián Muñoz-Leal reviewed the Portuguese "Resumo", and Diane Haughney reviewed the english text. This study has been funded by the FONDECYT No 1170972 and 1161593. We thanks Danny Fuentes for making the Figure 1.

\section{References}

Acosta-Jamett G, Contreras S, Muñoz P, Briceño C, Chirgwin C, Hernández F. Description of gastrointestinal parasitism through coprologic survey in Darwin's fox, Lycalopex fulvipes (Martin 1837), and kodkod, Leopardus guigna (Molina 1782), in Chiloé island, Chile. Gayana (Concepc) 2018; 82(2): 160-165. http://dx.doi.org/10.4067/S0717-65382018000200160.

Aguirre AA. Wild canids as sentinels of ecological health: A conservation medicine perspective. Parasit Vectors 2009; 2(Suppl 1): S7. http://dx.doi.org/10.1186/1756-3305-2-S1-S7. PMid:19426446.

Alcaíno H, Gorman T. Parásitos de los animales domésticos en Chile. Parasito/ Día 1999; 23(1-2): 33-41. http://dx.doi.org/10.4067/ S0716-07201999000100006.

Almeida GG, Coscarelli D, Melo MN, Melo AL, Pinto HA. Molecular identification of Spirometra spp. (Cestoda: Diphyllobothriidae) in some wild animals from Brazil. Parasitol Int 2016; 65(5 Pt A): 428-431. http://dx.doi.org/10.1016/j.parint.2016.05.014. PMid:27235572.

Al-Sabi MNS, Chriél M, Jensen TH, Enemark HL. Endoparasites of the raccoon dog (Nyctereutes procyonoides) and the red fox (Vulpes vulpes) in Denmark 2009-2012 - A comparative study. Int J Parasitol Parasites Wildl 2013; 2: 144-151. http://dx.doi.org/10.1016/j. ijppaw.2013.04.001. PMid:24533328.

Alvarez V. Investigaciones sobre echinococcosis silvestre en Chile. Biologia (Bratisl) 1961; 31: 89-94.

Alvarez V. Presencia de Linguatula serrata Froelich, 1789, en Dusicyon culpaeus y de formas ninfales en Octodon d. degus y Abrocoma b. benneti. Bol Chil Parasitol 1960; 15(2): 22. PMid:13793027.

Anderson RC, Chabaud AG, Willmott S. Keys to the nematode parasites of vertebrates: archival volume. Wallingford: CAB International; 2009. http://dx.doi.org/10.1079/9781845935726.0000.

Anderson RC. Nematode Parasites of Vertebrates: Their Development and Transmission. 2th ed. Wallingford: CABI Publishing; 2000. http://dx.doi.org/10.1079/9780851994215.0000.

Avelar IO, de Almeida LR, D'Elia ML, dos Santos HA, Soares DFM, Pereira PLL, et al. Pathological and parasitological findings in a Brazilian hoary fox (Lycalopex vetulus, Lund, 1842) infected by Oslerus osleri (Cobbold, 1876) (Nematoda: filaroididae). Braz J Vet Pathol 2013; 6(3): 111-115.

Bowman DD. Georgis' parasitology for veterinarians. 10th ed. St. Louis: Elsevier Saunders; 2014.

Briceño C, González-Acuña D, Jiménez JE, Bornscheuer ML, Funk SM, Knapp LA. Ear mites, Otodectes cynotis, on wild foxes (Pseudalopex spp.) in Chile.J Wildl Dis 2020; 56(1): 105-112. http://dx.doi.org/10.7589/2018-10-247. PMid:31329523.

Bružinskaitè-Schmidhalter R, Šarkūnas M, Malakauskas A, Mathis A, Torgerson PR, Deplazes P. Helminths of red foxes (Vulpes vulpes) and raccoon dogs (Nyctereutes procyonoides) in Lithuania. Parasitology 2011; 139(1): 120-127. http://dx.doi.org/10.1017/ S0031182011001715. PMid:21996514. 
Bush AO, Lafferty KD, Lotz JM, Shostak AW. Parasitology meets ecology on its own terms: Margolis et al. revisited. J Parasitol 1997; 83(4): 575-583.

Caballero E, Peregrina DI. Nematodos de los mamíferos de México I. Inst Biol Univ Nac Autónoma México. Ser Zool 1938; 9(3-4): 289-306.

Cattan PE, Núñez H, Yáñez J. Comunidades de parásitos en roedores: una comparación entre octodóntidos y cricétidos. Boletín Mus Nac Hist Nat Chile 1992; 43: 93-103.

Chile. Ministerio de Agricultura. SAG Ley N 19.473 y su reglamento. Santiago Servicio Agrícola y Ganadero; 2017.

Christoffersen ML, De Assis JE. A systematic monograph of the Recent Pentastomida, with a compilation of their hosts. Zool Meded 2013; 87: 1-206.

Courtin S, Alcaíno H, Plaza J, Ferriere G. Platelmintos del conejo silvestre (Oryctolagus cuniculus) en la cordillera de Nahuelbuta, Chile. Arch Med Vet 1979; 11(1): 23-26.

Daszak P, Cunningham A, Hyatt AD. Emerging infectious diseases of wildlife - threats to biodiversity and human health. Science 2000; 287(5452): 443-449. http://dx.doi.org/10.1126/science.287.5452.443. PMid:10642539.

Deem SL, Emmons LH. Exposure of free-ranging maned wolves (Chrysocyon brachyurus) to infectious and parasitic disease agents in the Noël Kempff Mercado National Park, Bolivia. J Zoo Wildl Med 2005; 36(2): 192-197. http://dx.doi.org/10.1638/04-076.1. PMid:17323558.

Dunsmore JD, Spratt DM. The life history of Filaroides osleri in wild and domestic canids in Australia. Vet Parasitol 1979; 5(2-3): 275-286. http://dx.doi.org/10.1016/0304-4017(79)90017-7.

Erickson AB. Helminths of Minnesota Canidae in relation to food habits, and a host list and key to the species reported from North America. Am Midl Nat 1944; 32(2): 358-372. http://dx.doi.org/10.2307/2421306.

Figueiredo A, Oliveira L, Madeira de Carvalho L, Fonseca C, Torres RT. Parasite species of the endangered Iberian wolf (Canis lupus signatus) and a sympatric widespread carnivore. Int J Parasitol Parasites Wildl 2016; 5(2): 164-167. http://dx.doi.org/10.1016/j. ijppaw.2016.04.002. PMid:27358768.

Fugassa MH. Checklist of helminths found in Patagonian wild mammals. Zootaxa 2015; 4012(2): 271-328. http://dx.doi. org/10.11646/zootaxa.4012.2.3. PMid:26623857.

Gomez-Puerta LA, Carrasco J, Lopez-Urbina MT, Gonzalez AE. Morphological and molecular identification of Spirocerca lupi (Nematoda: Spiruridae) found in the Andean fox (Lycalopex culpaeus).J Parasit Dis 2018; 42(3): 449-454. http://dx.doi.org/10.1007/ s12639-018-1009-8. PMid:30166794.

Gomez-Puerta LA, Pacheco JI, Angulo-Tisoc JM, Lopez-Urbina MT, Gonzalez AE. First finding of nymphal stages of Linguatula serrata in a South American camelid, a vicuña from Peru. Vet Parasito/ 2017; 244: 21-24. http://dx.doi.org/10.1016/j.vetpar.2017.07.019. PMid:28917312.

González CA, Milano AMF, Lunaschi LI. New findings of helminths parasites of Chrysocyon brachyurus (Carnivora: Canidae) in Argentina. Neotrop Helminthol 2013; 7(2): 265-270.

González-Acuña D, Briceño C, Cicchino A, Funk SM, Jiménez J. First records of Trichodectes canis (Insecta: Phthiraptera: Trichodectidae) from Darwin's fox, Pseudalopex fulvipes (Mammalia: Carnivora: Canidae). Eur J Wildl Res 2007; 53(1): 76-79. http:// dx.doi.org/10.1007/s10344-006-0066-y.

González-Acuña D, Guglielmone AA. Ticks (Acari: Ixodoidea: Argasidae, Ixodidae) of Chile. Exp Appl Acarol 2005; 35(1-2): 147-163. https://doi.org/10.1007/s10493-004-1988-2.

González-Acuña D, Lohse E, Cicchino A, Mironov S, Figueroa RA, Ardiles K, et al. Parasites of the American Kestrel (Falco sparverius) in South-Central Chile. J Raptor Res 2011; 45(2): 188-193.

González-Acuña D. Cysticercus tenuicollis en Pudues (Pudu pudu). Ciencia Ahora 2002; 5(9): 75-78.

Grandón-Ojeda A, Valdebenito JO, Moreno L, Kinsella JM, Mironov S, Cicchino A, et al. Gastrointestinal and external parasitism in the Magellanic Horned Owl Bubo magellanicus (Strigiformes: Strigidae) in Chile. Braz J Vet Parasitol 2018; 27(2): $161-168$.

Hofer S, Gloor S, Müller U, Mathis A, Hegglin D, Deplazes P. High prevalence of Echinococcus multilocularis in urban red foxes (Vulpes vulpes) and voles (Arvicola terrestris) in the city of Zürich, Switzerland. Parasitology 2000; 120(2): 135-142. http://dx.doi. org/10.1017/S0031182099005351. PMid:10726275.

Jiménez JE, Briceño C, Alcaíno H, Vásquez P, Funk S, González-Acuña D. Coprologic survey of endoparasites from Darwin's fox (Pseudalopex fulvipes) in Chiloé, Chile. Arch Med Vet 2012; 44(1): 93-97. http://dx.doi.org/10.4067/S0301-732X2012000100014.

Jiménez JE, Novaro AJ. Culpeo (Pseudalopex culpaeus). In: Sillero-Zubiri C, Hoffmann M, MacDonald DW. Canids: foxes, wolves, jackals and dogs. status survey and conservation action plan. Switzerland: IUCN/SSC Canid Specialist Group; 2004. p. $44-49$. 
Khalil L, Jones A, Bray R. Keys to the cestode parasite of vertebrates. London: CAB International; 1994

Landaeta-Aqueveque C, Robles MDR, Henríquez A, Yáñez-Meza A, Correa JP, González-Acuña D, et al. Phylogenetic and ecological factors affecting the sharing of helminths between native and introduced rodents in Central Chile. Parasitology 2018; 145(12): 1570-1576. http://dx.doi.org/10.1017/S0031182018000446. PMid:29886859.

Lima RC, Hoppe EGL, Tebaldi JH, Cruz BC, Gomes AAB, Nascimento AA. Gastrintestinal helminths of Cerdocyon thous (Linnaeus, 1766 - Smith, 1839) from the caatinga area of the Paraíba State, Brazil. Semina: Ciênc Agrár 2013; 34(6): 2879-2888. http://dx.doi. org/10.5433/1679-0359.2013v34n6p2879.

Luengo M, Arata N. Filarioides osleri como hallazgo de necropsia en canino. Bol Chil Parasitol 1970; 25(1): 87-88. PMid:5480208.

Lutz HL, Tkach V, Weckstein JD. Methods for specimen-based studies of avian symbionts. In: Webster MS. The extended specimen: emerging frontiers in collections-based ornithological research. Boca Raton: CRC Press; 2017. p. 157-183.

Martínez DR, Rau JR, Murua RE, Tilleria MS. Depredación selectiva de roedores por zorros chillas (Pseudalopex griseus) en la pluviselva valdiviana, Chile. Rev Chil Hist Nat 1993; 66(1): 419-426.

Medel R, Jaksic FM. Ecología de los cánidos sudamericanos: una revisión. Rev Chil Hist Nat 1988; 61(1): 67-79.

Mey E. Verzeichnis der tierläuse (Phthiraptera) Deutschlands. Entomofauna Germanica 2003; 6: 72-129.

Moleón MS, Kinsella JM, Moreno PG, Ferreyra HV, Pereira J, Pía M, et al. New hosts and localities for helminths of carnivores in Argentina. Zootaxa 2015; 4057(1): 106-114. http://dx.doi.org/10.11646/zootaxa.4057.1.6. PMid:26701468.

Morgan BB. The Physaloptera (Nematoda) of carnivores. Wisconsin Acad Sci Arts Lett 1944; 36: 375-388.

Moro PL, Ballarta J, Gilman RH, Leguia G, Rojas M, Montes G. Intestinal parasites of the grey fox (Pseudalopex culpaeus) in the central Peruvian Andes. J Helminthol 1998; 72(1): 87-89. http://dx.doi.org/10.1017/S0022149X00001048. PMid:9639908.

Muñoz L, Fredes F, Faundez P, Sanz L, González C. Tos crónica en un perro asociada a Filaroides osleri. Parasitol Latinoam 2007; 62(1-2): 72-75. http://dx.doi.org/10.4067/S0717-77122007000100012.

Naem S, Asadi R. Ultrastructural characterization of male and female Physaloptera rara (Spirurida: Physalopteridae): Feline stomach worms. Parasitol Res 2013; 112(5): 1983-1990. http://dx.doi.org/10.1007/s00436-013-3356-9. PMid:23455940.

Okulewicz A, Perec-Matysiak A, Buńkowska K, Hildebrand J. Toxocara canis, Toxocara cati and Toxascaris leonina in wild and domestic carnivores. Helminthologia 2012; 49(1): 3-10. http://dx.doi.org/10.2478/s11687-012-0001-6.

Oyarzún-Ruiz P, González-Acuña D. Colecta, preparación e identificación de parásitos. Parasitol Latinoam 2020; 69(1): $12-29$.

Padgett KA, Nadler SA, Munson L, Sacks B, Boyce WM. Systematics of Mesocestoides (Cestoda: Mesocestoididae): evaluation of molecular and morphological variation among isolates.J Parasitol 2005; 91(6): 1435-1443. http://dx.doi.org/10.1645/GE-3461.1. PMid:16539028.

Petrochenko VI. Acanthocephala of domestic and wild animals. Vol. 2. Moscow: Izdatel'stvo Akademii Nauk SSSR; 1958.

Pinheiro RHS, Chaves IBP, Rodrigues RAR, Branco É, Lima AR, Giese EG. Nematode capilaridae in the tongue of Cerdocyon thous of free life in Brazil. Braz J Vet Parasitol 2018; 27(4): 531-544.

Poo-Muñoz DA, Elizondo-Patrone C, Escobar LE, Astorga F, Bermúdez SE, Martínez-Valdebenito C, et al. Fleas and ticks in carnivores from a domestic-wildlife interface: implications for public health and wildlife. J Med Entomol 2016; 53(6): 1433-1443. http://dx.doi.org/10.1093/jme/tjw124. PMid:27539151.

Poulin R. Evolutionary ecology of parasites. 2nd ed. New Jersey: Princeton University Press; 2007.

Povilitis A. Characteristics and conservation of a fragmented population of huemul Hippocamelus bisulcus in central Chile. Biol Conserv 1998; 86(1): 97-104. http://dx.doi.org/10.1016/S0006-3207(97)00161-4.

Quentin J-C, Karimi Y, Rodriguez de Almeida C. Protospirura numidica criceticola, n. subsp. parasite de Rongeurs Cricetidae du Brésil. Cycle évolutif. Ann Parasitol Hum Comp 1968; 43(5): 583-596. http://dx.doi.org/10.1051/parasite/1968435583. PMid:5719305.

Rego AA, Schäffer GV. Sparganum in some Brazilian vertebrates. Problems in the identification of species of Luheella (Spirometra). Mem Inst Oswaldo Cruz 1992; 87(Suppl. 1): 213-216. http://dx.doi.org/10.1590/S0074-02761992000500040. PMid:1343790.

Riley J. The Biology of Pentastomids. Adv Parasitol 1986; 25: 45-128. http://dx.doi.org/10.1016/S0065-308X(08)60342-5. PMid:3535437.

Rojas A, Sanchis-Monsonís G, Alić A, Hodžić A, Otranto D, Yasur-Landau D, et al. Spirocerca vulpis sp. nov. (Spiruridae: Spirocercidae): description of a new nematode species of the red fox, Vulpes vulpes (Carnivora: Canidae). Parasitology 2018; 145(14): 1917-1928. http://dx.doi.org/10.1017/S0031182018000707. PMid:29781422.

Ruas JL, Muller G, Farias NAR, Gallina T, Lucas AS, Pappen FG, et al. Helmintos do cachorro do campo, Pseudalopex gymnocercus (Fischer, 1814) e do cachorro do mato, Cerdocyon thous (Linnaeus, 1766) no sul do estado do Rio Grande do Sul, Brasil. Braz J Vet Parasitol 2008; 17(2): 87-92. 
Rubio A, Fredes F, Bonacic C. Serological and parasitological survey of free-ranging culpeo foxes (Lycalopex culpaeus) in the mediterranean biodiversity hotspot of central Chile. J Anim Vet Adv 2013; 12(18): 1445-1449.

Santos CP, Simões SBE, Barbosa HS, Scholz T. Redescription of Ascocotyle (Ascocotyle) felippei Travassos, 1928 (Digenea: Heterophiydae) with new synonymies. J Parasitol 2007; 93(6): 1468-1475. http://dx.doi.org/10.1645/GE-1212.1. PMid:18314695.

Seesee FM, Sterner MC, Worley DE. Helminths of the Coyote (Canis latrans Say) in Montana. J Wildl Dis 1983; 19(1): 54-55. http:// dx.doi.org/10.7589/0090-3558-19.1.54. PMid:6842734.

Shimalov VV, Shimalov V. Helminth fauna of the racoon dog (Nyctereutes procyonoides Gray, 1834) in Belorussian Polesie. Parasitol Res 2002; 88(10): 944-945. http://dx.doi.org/10.1007/s00436-001-0582-3. PMid:12209337.

Shimalov VV, Shimalov VT. Helminth fauna of the red fox (Vulpes vulpes Linnaeus, 1758) in southern Belarus. Parasitol Res 2003; 89(1): 77-78. PMid:12474048.

Stein M, Suriano DM, Novaro AJ. Nematodes parásitos de Dusycion griseus (Gray, 1837), D. culpaeus (Molina, 1782) and Conepatus chinga (Molina, 1782) (Mamífera: Carnívora) en Neuquén, Argentina: Sistemática y ecología. Bol Chil Parasitol 1994; 49(3-4): 6065. PMid:7654286.

Verdugo C, Espinoza A, Moroni M, Valderrama R, Hernandez C. Sarcoptic Mange in a South American Gray Fox (Chilla Fox; Lycalopex griseus), Chile. J Wildl Dis 2016; 52(3): 738-741. http://dx.doi.org/10.7589/2015-07-177. PMid:27310169.

Vicente JJ, Rodrigues HDO, Gomes DC, Pinto RM. Nematóides do Brasil. Parte V: nematóides de mamíferos. Rev Bras Zool 1997; 14(Suppl. 1): 1-452. http://dx.doi.org/10.1590/S0101-81751997000500001.

Vieira FM, Luque JL, Muniz-Pereira LC. Checklist of helminth parasites in wild carnivore mammals from Brazil. Zootaxa 2008; 1721(1): 1-23. http://dx.doi.org/10.11646/zootaxa.1721.1.1.

Wolffhügel K. ¿Es autóctono el Diphyllobotrium en Chile? Bol Soc Biol Concepc 1949; 24: 85-89.

Yamaguti S. Systema helminthum. Vol. 3 - The nematodes of vertebrates. New York: Interscience Publishers Inc.; 1961

Zanini F, Laferrara M, Bitsch M, Pérez H, Elissondo MC. Epidemiological studies on intestinal helminth parasites of the patagonian grey fox (Pseudalopex griseus) in Tierra del Fuego, Patagonia Argentina. Vet Parasitol 2006; 136(3-4): 329-334. http://dx.doi. org/10.1016/j.vetpar.2005.11.014. PMid:16414190. 